\title{
Pembelajaran Interaktif Pemrograman Web dengan Menggunakan Media CMS bagi Guru dan Siswa SMKN 1 Kamal
}

\author{
Noor Ifada dan Sri Wahyuni \\ Fakultas Teknik, Universitas Trunojoyo Madura \\ Email: noor.ifada@trunojoyo.ac.id \\ DOI: https://doi.org/10.21107/pangabdhi.v5i2.6109
}

Artikel Diterima : 12 Agustus 2019/ Revisi : 7 September 2019/Terbit : 19 Oktober 2019

\begin{abstract}
Abstrak
Selama ini, pembelajaran pemrograman web di SMKN 1 Kamal dilaksanakan dengan metode konvensional dimana aplikasi penyunting teks dan web browser dibuka dalam window yang terpisah. Jadi proses pembelajaran dilaksanakan dalam dua tahapan, yaitu dari membuka window pertama untuk membuat skrip program dan kemudian membuka window kedua untuk untuk melihat hasilnya. Meskipun metode ini umum dan mudah untuk diterapkan, namun proses pembelajarannya menjadi kurang iteraktif. Tujuan dari kegiatan ini adalah memberikan pengenalan dan pelatihan CMS yang digunakan sebagai media pembelajaran interaktif untuk mata pelajaran pemrograman web bagi guru dan siswa di SMKN 1 Kamal. Aplikasi CMS yang digunakan adalah WordPress, yaitu aplikasi CMS yang sangat populer dan memiliki fitur $t a b$ yang memungkinkan terjadinya pergantian pilihan antara aplikasi penyunting teks skrip program dengan aplikasi tampilan dalam web browser di dalam satu window yang sama, Kegiatan terbagi menjadi lima tahapan, yaitu: persiapan pelaksanaan pelatihan, persiapan kelengkapan pelatihan, pelaksanaan pelatihan, pelaksanaan pendampingan, dan dokumentasi akhir. Hasil evaluasi kegiatan menyatakan bahwa kegiatan dianggap berhasil karena: (a) pendaftar kegiatan sesuai dengan target, (b) kegiatan pelatihan berlangsung lancar dengan hadirnya seluruh peserta secara lengkap dan tepat waktu, (c) setiap peserta dapat melakukan instalasi WordPress serta dapat menggunakannya dengan baik selama pelatihan, (d) seluruh peserta mampu menangkap penjelasan dari materi pelatihan sehingga dapat mengerjakan soal latihan yang diberikan dengan baik, dan (e) seluruh peserta mampu mengerjakan tugas mandiri yaitu membuat halaman web dengan menggunakan WordPress.
\end{abstract}

Kata Kunci: CMS, media pembelajaran interaktif, pemrograman web, WordPress

\begin{abstract}
SMKN 1 Kamal had been implementing the web programming conventional teaching method that the text editor and web browser applications were used separately. In this case, two-stage of learning processes were applied one after the other, i.e., creating the programming script using the text editor application, and check the result using the web browser application afterwards. This teaching method is widely implemented, yet the learning process is not interactive. The purpose of this programme is to train the teachers and students in SMKN 1 Kamal to use CMS as an interactive web programming learning media. We use the WordPress CMS as it is very popular and has a tab feature that allows us to easily toggle between the text editor and browser applications in a single window. The programme is organized into five stages: training preparation, training fittings preparation, training session, assistance session, and final documentation. Our evaluations show that the programme is successfully accomplished given that: (a) the number registrars matches our target, (b) the training sessions are well-conducted based on the attendance of participants, (c) each training participant is able to instal and use WordPress accordingly, (d) all training participants are able to solve the practice questions, showing that they have sufficient comprehension regarding the training materials, and (e) all participants are able to finish their project tasks, i.e., building websites using WordPress.
\end{abstract}

Keyword: CMS, interactive learning media, web programming, WordPress

\section{PENDAHULUAN}

Memiliki keahlian di bidang pemrograman web merupakan salah satu kompetensi keahlian yang harus dimiliki oleh setiap lulusan SMK RPL sesuai dengan yang tercantum dalam struktur kurikulumnya (Menengah, 2018). Pemrograman web adalah salah satu aspek penting dalam pengembangan web. Web itu sendiri dapat dibagi menjadi dua jenis, yaitu web statis dan web dinamis. Web statis merupakan jenis situs web yang menampilkan informasi yang sifatnya statis (tetap). Teknologi yang digunakan untuk 
membangun sistem ini berbasis client-side dan fokus pada pengembangan web di sisi front-end. Web dinamis merupakan jenis situs web yang menampilkan informasi yang sifatnya dinamis dan/atau memproses data yang dikirimkan oleh user, serta seringkali memerlukan akses basisdata. Teknologi yang digunakan merupakan gabungan dari teknologi berbasis client-side dan server-side. Teknologi berbasis server-side fokus pada pengembangan web di sisi back-end. Berdasarkan deskripsi kedua web, jelaslah bahwa keahlian untuk mengembangkan web statis merupakan dasar utama bagi pengembangan web dinamis.

Bahasa yang digunakan dalam pengembangan web statis adalah bahasa standar yang merupakan hasil kerja sama antara W3C (World Wide Web Consortium) dan WHATWG (Web Hypertext Application Technology Working Group) (Krause, 2016). Bahasa standar yang dimaksud di sini adalah HTML (HyperText Markup Language), CSS (Cascading Style Sheet), dan JavaScript.

Pembelajaran pemrograman web untuk pengembangan web statis membutuhkan penggunaan dua buah aplikasi. Aplikasi pertama adalah aplikasi penyunting teks yang digunakan untuk membuat skrip program. Contoh aplikasi penyunting teks adalah Notepad++, Sublime, Brackets, dan lain-lain. Aplikasi kedua adalah web browser yang digunakan untuk membuka halaman web sebagai hasil eksekusi dari skrip program yang dibuat dalam aplikasi pertama. Contoh web browser adalah Google Chrome, Mozilla Firefox, Internet Explorer, dan lain-lain.

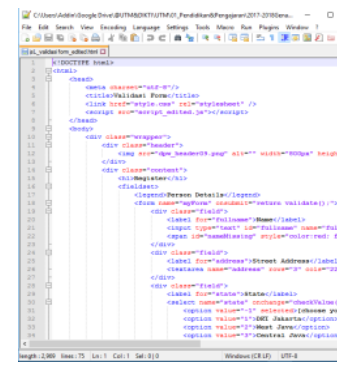

(a)

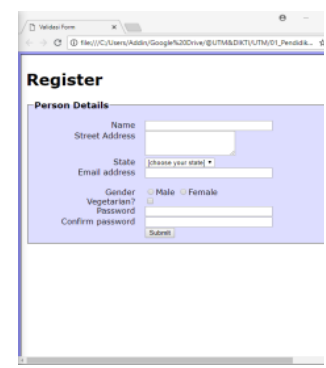

(b)
Gambar 1. Aplikasi untuk pemrograman web statis: (a) Aplikasi penyunting teks untuk membuat skrip program dan (b) Aplikasi web browser untuk membuka dokumen web

Selama ini, pembelajaran pemrograman web dilaksanakan dengan metode konvensional dimana aplikasi penyunting teks dan web browser dibuka dalam window yang terpisah (lihat Gambar 1). Jadi proses pembelajaran dilaksanakan dalam dua tahapan, yaitu dari membuka window pertama untuk membuat skrip program dan kemudian membuka window kedua untuk untuk melihat hasilnya. Meskipun metode ini umum dan mudah untuk diterapkan, namun proses pembelajarannya menjadi kurang iteraktif.

Metode pembelajaran akan menjadi interaktif apabila kedua aplikasi tersebut dapat ditampilkan dalam satu kesatuan window, sehingga ketika skrip program dibuat maka hasilnya akan langsung dapat dilihat di dalam window yang sama. Metode interaktif ini diterapkan oleh situs pembelajaran pengembangan web secara online yang sangat populer seperti W3schools.com (www.w3schools.com) dan Khan Academy (www.khanacademy.org/). Contoh tampilan media pembelajaran interaktif untuk pemrograman web di W3schools.com dan Khan Academy dapat dilihat dalam Gambar 2 dan Gambar 3. Dari kedua gambar tersebut terlihat jelas bahwa aplikasi penyunting teks (sisi kiri) dan aplikasi web browser (sisi kanan) berada dalam satu window yang sama.

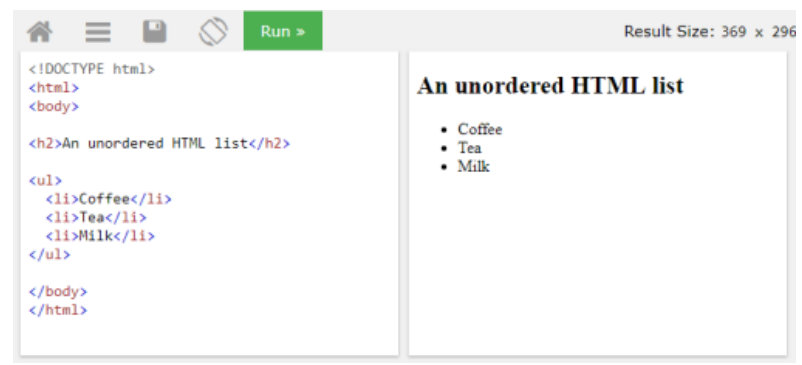

Gambar 2. Media pembelajaran interaktif untuk pemrograman web di W3schools.com

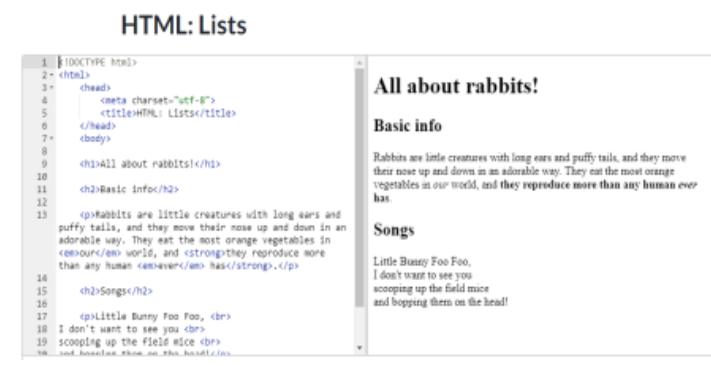

Gambar 3. Media pembelajaran interaktif untuk pemrograman web di Khan Academy

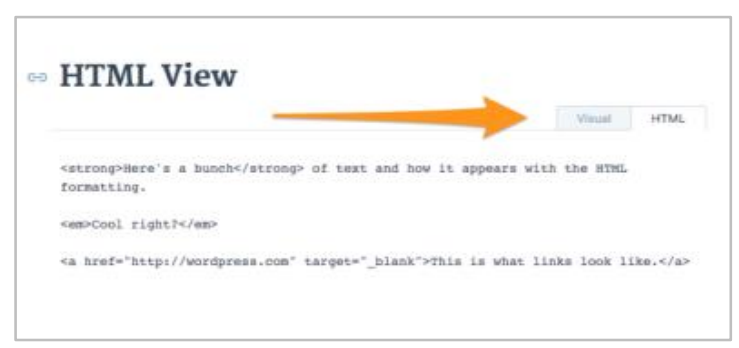

Gambar 4. Fitur tab untuk pergantian aplikasi penyunting teks skrip program (tab HTML) 
dengan aplikasi tampilan dalam web browser (tab Visual)

Salah satu media pembelajaran interaktif untuk pemrograman web adalah dengan memanfaatkan CMS (Content Management System) (Lovreković \& Lovreković, 2015). CMS adalah suatu aplikasi yang digunakan untuk membuat atau mengelola konten digital. Di dunia kerja, memiliki keahlian dibidang CMS bahkan menjadi salah satu kualifikasi wajib untuk dimiliki ketika melamar pekerjaan (Wardhani, 2018), khususnya di bidang Teknologi Informasi (TI). CMS yang paling populer digunakan saat ini adalah WordPress (Lab, 2018), dengan klaim jumlah penggunaan sebesar 31\% dari keseluruhan web yang ada. Salah satu fitur yang tersedia dalam WordPress adalah fitur tab yang memungkinkan terjadinya pergantian pilihan antara aplikasi penyunting teks skrip program (tab HTML) dengan aplikasi tampilan dalam web browser (tab Visual) di dalam satu window yang sama, seperti yang diperlihatkan dalam Gambar 4.

Tujuan dari kegiatan Program Kemitraan Masyarakat (PKM) ini adalah memberikan pengenalan dan pelatihan fitur yang ada di dalam WordPress sebagai media pembelajaran interaktif untuk mata pelajaran pemrograman web bagi guru dan siswa di SMK.

\section{METODE}

Mitra dalam kegiatan Program Kemitraan Masyarakat (PKM) ini adalah SMKN 1 Kamal, salah satu SMK negeri di kabupaten Bangkalan yang memiliki kompetensi keahlian RPL. Kegiatan PKM dilaksanakan dalam jangka waktu delapan bulan. Kegiatan terbagi menjadi lima tahapan berikut:

\section{Tahap Persiapan Pelaksanaan Pelatihan}

Dalam tahap ini dilakukan proses persiapan pelaksanaan kegiatan pelatihan. Terdapat lima kegiatan yang dilakukan dalam tahap ini, yaitu:

- Perencanaan pelaksanaan kegiatan, yaitu meliputi sosialisasi, pelatihan, dan pendampingan

- Pembuatan undangan sosialisasi untuk membahas pelaksanaan jadwal kegiatan pelatihan dan pendampingan

- Penyebaran undangan kepada sekolah mitra yaitu SMKN 1 Kamal

- Penerimaan pendaftaran peserta pelatihan. Sekolah mitra dapat mengirimkan 6 orang calon peserta yang terdiri dari 3 guru dan 3 siswa dengan kualifikasi Teknologi Informasi
Komunikasi (TIK) dari kompetensi keahlian Rekayasa Perangkat Lunak. Siswa dilibatkan dalam pelatihan dengan harapan agar implementasi hasil pelatihan di sekolah mitra nanti dapat berjalan dengan lebih mudah karena guru sedari awal dapat melihat dan menilai tanggapan dan kemampuan siswa terhadap metode pembelajaran interaktif dengan WordPress untuk pemrograman web statis

- Pemberian informasi kepada peserta pelatihan (Gambar 5) untuk mempersiapkan skrip pemrograman web dengan menggunakan HTML, CSS, dan JavaScript. Skrip ini nanti akan dipraktikkan di sekolah masing-masing setelah kegiatan pelatihan selesai

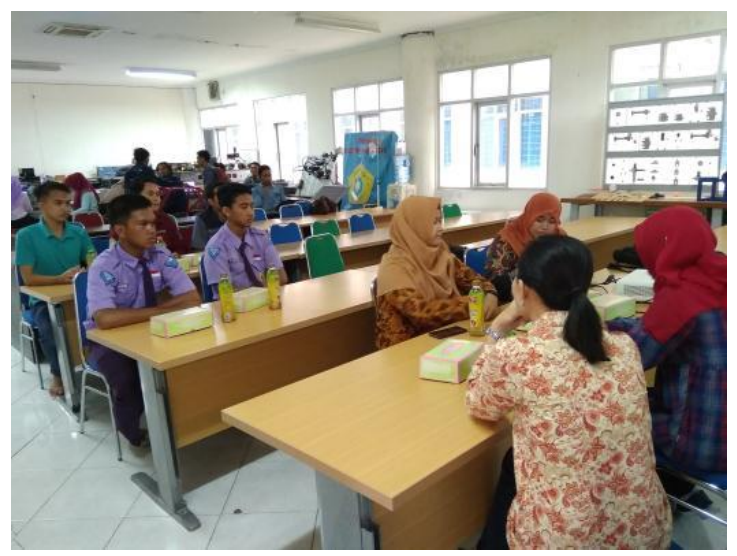

Gambar 5. Dokumentasi sosialisasi PKM

\section{Tahap Persiapan Kelengkapan Pelatihan}

Dalam tahap ini akan dilakukan proses persiapan kelengkapan kegiatan pelatihan. Terdapat empat kegiatan yang dilakukan dalam tahap ini, yaitu:

- Penjadwalan peminjaman ruang Laboratorium Sistem Cerdas dan Robotika yang dimiliki oleh Program Studi Teknik Mekatronika, yaitu tempat pelaksanaan pelatihan dengan fasilitas LCD, papan tulis, AC dan CCTV yang dibutuhkan untuk kegiatan pelatihan

- Persiapan aplikasi WordPress yang digunakan dalam pelatihan

- Pembuatan modul sebagai bahan materi yang akan diberikan dalam pelatihan. Modul ini berupa teori dan permasalahan yang dapat membantu peserta pelatihan untuk memahami materi

- Persiapan media presentasi yaitu LCD dan slide presentasi yang dibuat oleh pemateri 


\section{Jurnal Pangabdhi}

\section{Tahap Pelaksanaan Pelatihan}

Dalam tahap ini dilakukan pelaksanaan pelatihan sesuai dengan jadwal yang telah disepakati ketika sosialisasi kegiatan dilakukan. Jadwal ini dibuat dengan mempertimbangkan waktu yang memungkinkan bagi peserta guru dari sekolah mitra untuk mengikuti kegiatan pelatihan di tengah kesibukan mereka dengan kegiatan mengajar di sekolah.

Pendataan ulang peserta dilakukan di sini berdasarkan informasi yang diperoleh pada saat pendaftaran peserta yang dilaksanakan dalam tahap persiapan pelaksanaan pelatihan. Untuk mendukung kegiatan pelatihan, setiap peserta akan menerima fasilitas blocknote, alat tulis, modul pelatihan, dan flaskdisk berisi instalasi WordPress.

Terdapat empat kegiatan yang dilakukan dalam tahap ini, yaitu:

- Pelatihan instalasi WordPress (Gambar 7)

- Pelatihan penggunaan HTML dalam WordPress (Gambar 7)

- Pelatihan penggunaan CSS dalam WordPress (Gambar 8)

- Pelatihan penggunaan JavaScript dalam WordPress (Gambar 9)

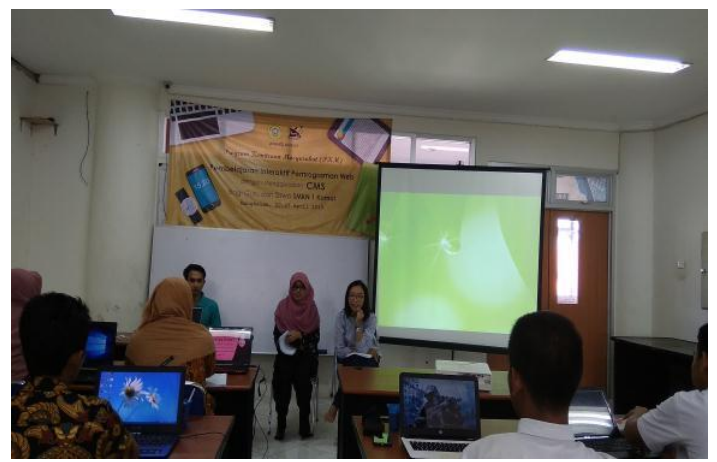

Gambar 6. Dokumentasi pembukaan pelatihan

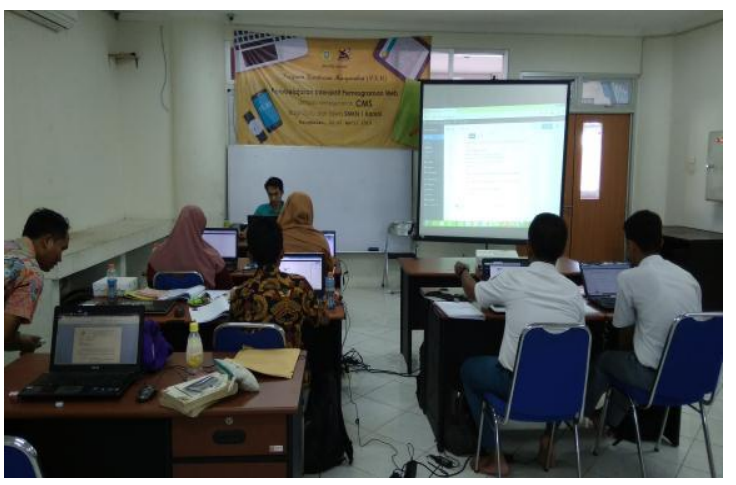

Gambar 7. Dokumentasi pelatihan instalasi WordPress dan HTML

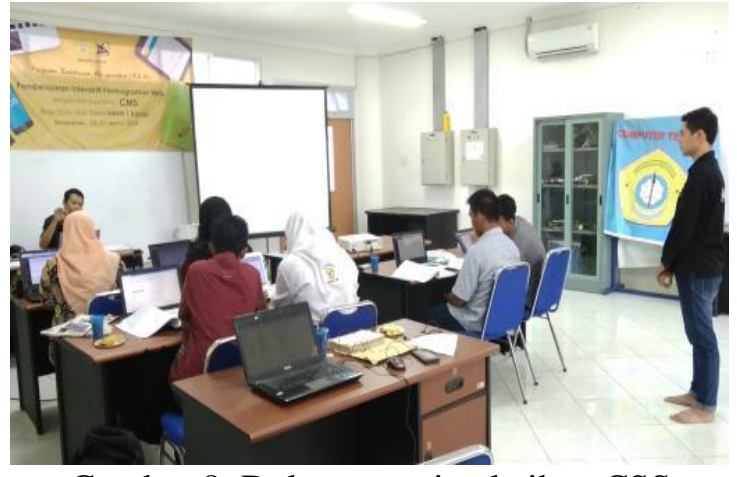

Gambar 8. Dokumentasi pelatihan CSS

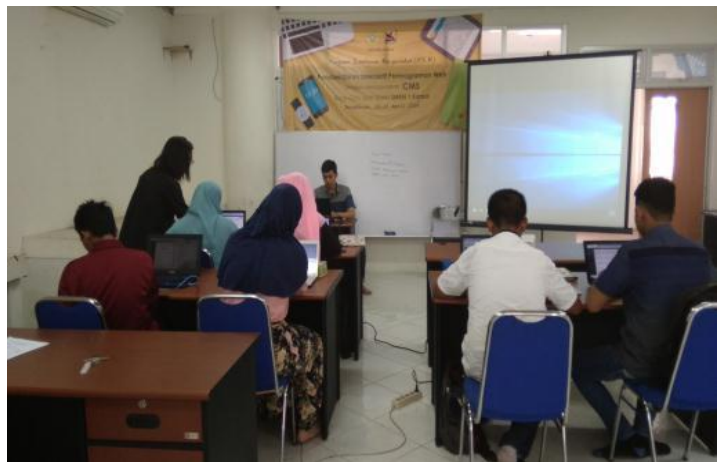

Gambar 9. Dokumentasi pelatihan JavaScript

\section{Tahap Pelaksanaan Pendampingan}

Dalam tahap ini dilakukan pendampingan di sekolah mitra setelah pelaksanaan kegiatan pelatihan. Pendampingan dilakukan dengan terlebih dahulu menyesuaikan jadwal antara tim dengan guru dan siswa. Kegiatan pendampingan adalah untuk melakukan pengecekan apakah ada permasalahan yang dihadapi guru dan siswa pada saat mempraktekkan skrip yang mereka buat sendiri dengan menggunakan WordPress (

Gambar 10 dan Gambar 11). Total pendampingan dilakukan sebanyak lima kali pertemuan.

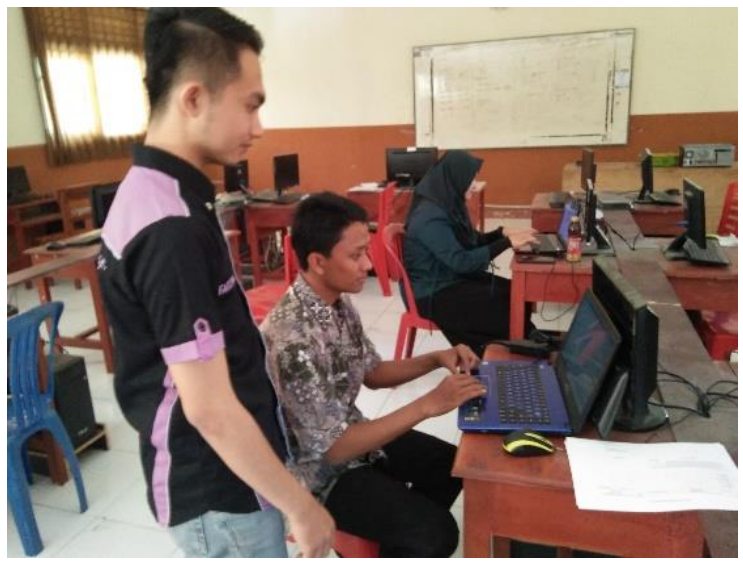

Gambar 10. Dokumentasi pendampingan guru 


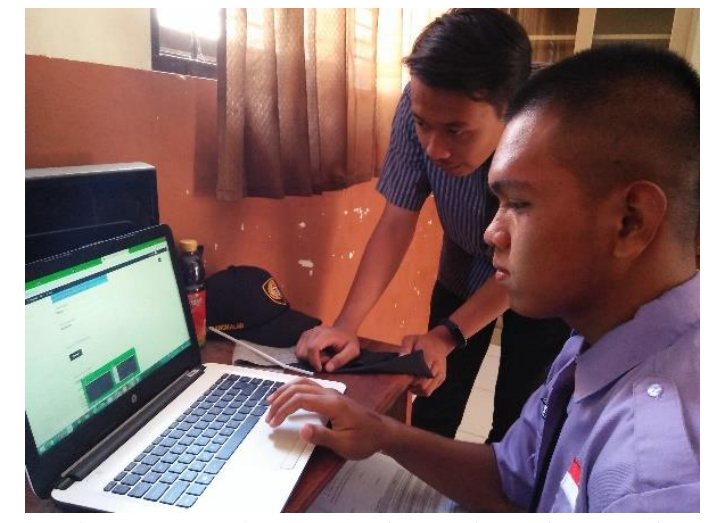

Gambar 11. Dokumentasi pendampingan siswa

\section{Tahap Dokumentasi akhir}

Dalam tahap ini dilakukan penutupan program PKM. Dokumentasi sebagai laporan akhir yang nantinya akan dikirim ke DIKTI. Laporan ini berisi tentang penjabaran kegiatan pelatihan, pendampingan, evaluasi dan dokumentasi kegiatan lainnya.

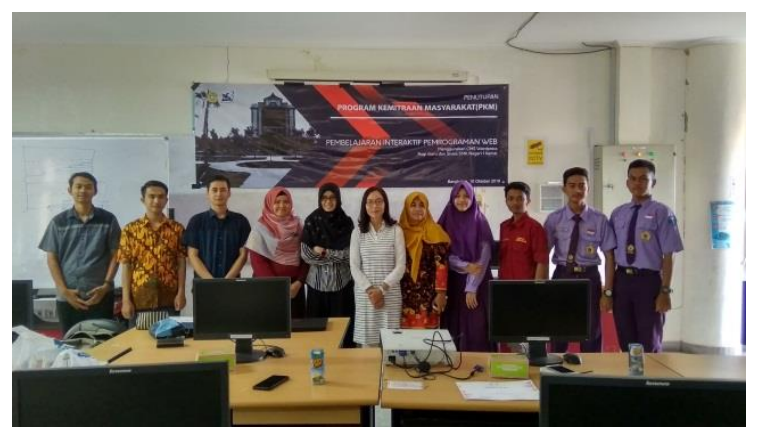

Gambar 12. Dokumentasi penutupan program

\section{HASIL DAN PEMBAHASAN}

Berdasarkan lima tahapan pelaksanaan kegiatan yang telah dijelaskan sebelumnya, kami melakukan dua tingkatan evaluasi berikut:

\section{Evaluasi Tahap Pertama}

Tingkatan evaluasi ini dilakukan setelah sosialisasi pada dua sekolah mitra. Indikator keberhasilan dari evaluasi tahap pertama adalah adanya minat sekolah yang diundang untuk mendaftarkan diri sebagai peserta pelatihan pembelajaran interaktif permrograman web dan kemauan untuk melengkapkan persyaratan yang diminta oleh panitia. Indikator keberhasilannya: sekolah mitra SMKN 1 Kamal mengikuti kegiatan sosialisasi, hadir pada undangan sosialisasi dan mendaftarkan 6 (enam) orang peserta yang terdiri dari guru dan siswa/siswi.

Hasil evaluasi tahap pertama adalah berhasil, yaitu bahwa kami menerima pendaftaran 6 (enam) orang peserta dari SMKN 1 Kamal setelah sosialisasi dilakukan. Rincian peserta adalah 3 (tiga) orang guru dari jurusan RPL pengampu pelajaran pemrograman web dan 3 (tiga) orang siswa/siswi dari jurusan yang sama.

\section{Evaluasi Tahap Kedua}

Tingkatan evaluasi ini dilakukan setelah pelaksanaan pelatihan. Setiap peserta diberikan beberapa kali latihan soal yang berkaitan dengan materi, secara berselang-seling antara penjelasan teori dan latihan. Indikator keberhasilan dari evaluasi tahap kedua adalah bahwa kegiatan pelatihan berlangsung lancar dengan hadirnya 6 (enam) peserta secara lengkap dan tepat waktu, seluruh peserta memahami pentingnya CMS dan instalasi WordPress yang diberikan dalam Modul Pendahuluan (Gambar 13), seluruh peserta mampu mengerjakan tugas latihan modul pelatihan $2-7$ (Gambar 13), seluruh peserta mampu mengerjakan tugas mandiri yaitu halaman web dengan kombinasi HTML, CSS dan JavaScript dengan menggunakan WordPress.

Hasil evaluasi tahap kedua adalah berhasil, yaitu bahwa:

1. Kegiatan pelatihan berlangsung lancar, dengan hadirnya 6 (enam) peserta secara lengkap dan tepat waktu

2. Masing-masing peserta dapat melakukan instalasi WordPress (modul Pendahuluan) pada laptop pribadinya sehingga dapat digunakan dengan baik untuk pelatihan.

3. Adanya kemampuan peserta untuk menangkap penjelasan dari materi pelatihan, terbukti dengan kemampuan mengerjakan soal latihan yang diberikan dari modul $2-7$ dengan baik.

4. Seluruh peserta mampu mengerjakan tugas mandiri yaitu membuat halaman web yang mengkombinasikan HTML, CSS dan JavaScript dengan menggunakan WordPress. Gambar 14 memperlihatkan dua contoh hasil tugas mandiri.

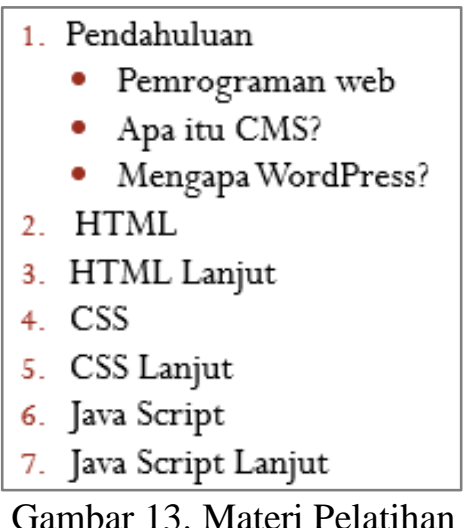

Gambar 13. Materi Pelatihan 

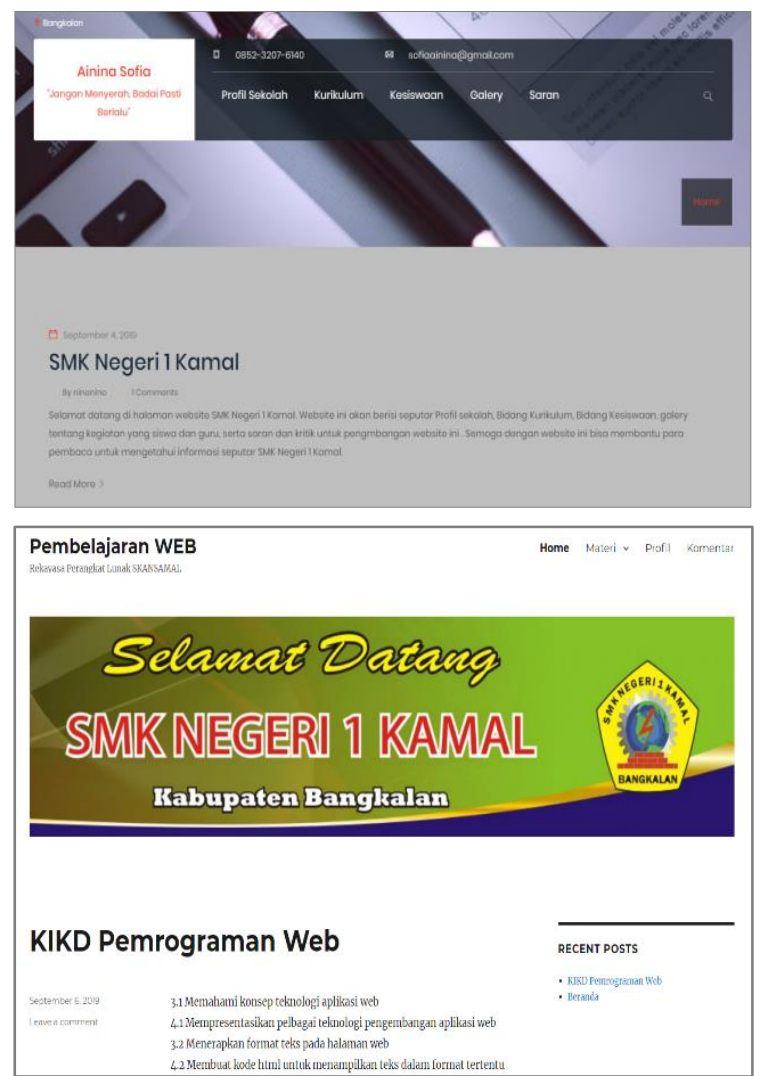

Gambar 14. Tampilan Halaman Web Site

\section{KESIMPULAN}

Kegiatan PKM berbentuk pembelajaran interaktif mata pelajaran Pemrograman Web dengan menggunakan media CMS bagi Guru dan Siswa SMKN 1 Kamal telah berhasil dilaksanakan dengan hasil keberhasilan sebagai berikut:

1. Pendaftar kegiatan adalah 6 (enam) orang peserta yang terdiri dari 3 (tiga) orang guru dari jurusan RPL pengampu pelajaran pemrograman web dan 3 (tiga) orang siswa/siswi dari jurusan yang sama.

2. Kegiatan pelatihan berlangsung lancar, dengan hadirnya 6 (enam) peserta secara lengkap dan tepat waktu

3. Masing-masing peserta dapat melakukan instalasi WordPress dan dapat menggunakannya dengan baik selama pelatihan.

4. Seluruh peserta mampu menangkap penjelasan dari materi pelatihan sehingga dapat mengerjakan soal latihan yang diberikan dengan baik.

5. Seluruh peserta mampu mengerjakan tugas mandiri yaitu membuat halaman web yang mengkombinasikan HTML, CSS dan JavaScript dengan menggunakan WordPress
Sebagai keberlanjutan dari kegiatan PKM ini, tim kami berencana untuk mengadakan kegiatan pemanfaatan media CMS untuk pembelajaran Pengembangan Web Dinamis bagi Guru dan Siswa SMKN 1 Kamal.

\section{UCAPAN TERIMA KASIH}

Program ini didanai oleh Kementerian Riset, Teknologi dan Pendidikan Tinggi sesuai dengan Perjanjian Pendanaan Pelaksanaan Program Pengabdian Masyarakat Nomor: 103/SP2H/PPM/DRPM/2019.

\section{DAFTAR PUSTAKA}

Krause, J. 2016. Introducing Web Development. Berlin: Apress.

Lab, S. 2018. The Top 20 Most Popular Content Management Software. Retrieved from https://www.capterra.com/contentmanagement-software/\#infographic

Lovreković, Z. T., \& Lovreković, T. Z. 2015. CMS as a web programming learning tool. International Journal of Process Management - New Technologies (JPMNT), Vol 3(4).

Menengah, D. J. P. D. d. (2018). Peraturan Direktur Jenderal Pendidikan Dasar dan Menengah Kementerian Pendidikan dan Kebudayaan No. 07/D.D5/KK/2018 tentang Struktur Kurikulum Sekolah Menengah Kejuruan (SMK)/Madrasah Aliyah Kejuruan (MAK). Jakarta

Wardhani, A. T. (2018). 5 Keahlian yang Wajib Dimiliki Pencari Kerja Zaman Now. Retrieved from https://www.liputan6.com/lifestyle/read/322 7288/5-keahlian-yang-wajib-dimilikipencari-kerja-zaman-now 

Volume 5, No. 2, Oktober 2019

http://journal.trunojoyo.ac.id/pangabdhi

ISSN: 2477-6289 